\title{
Pemanfaatan Limbah Plastik Untuk Pembuatan Paving block
}

\author{
Sudarno $^{1}$, Seska Nicolaas ${ }^{2}$, Vicky Assa ${ }^{3}$ \\ Program Studi Diploma III Teknik Sipil, Jurusan Teknik Sipil, Politeknik Negeri Manado, \\ Kota Manado \\ E-mail korepondensi: ${ }^{1}$ Sudarno_74@yahoo.co.id
}

\begin{abstract}
Abstrak
Limbah plastik yang tadinya hanya sebagai barang buangan kotor, berbau dan banyak menimbulkan penyakit serta mencemari lingkungan, sebenarnya dapat dimanfaatkan menjadi berbagai macam bahan konstruksi ringan yang bermanfaat dalam kehidupan manusia. Hal ini karena selain dapat dimanfaatkan dari segi teknis, bahan olahan dari sampah plastik juga memiliki nilai ekonomi yang tinggi. Penelitian ini bertujuan untuk mengurangi polusi limbah plastik yang mencemari lingkungan hidup dan mendapatkan campuran terbaik pada limbah plastik untuk pembuatan paving block, mengetahui besarnya nilai kuat tekan dan lentur paving block plastik dan agregat kasar, dengan membandingkan biaya per $m^{2}$ antara paving dari limbah plastik dan paving normal. Penelitian ini dilaksanakan di Laboratorium Uji Bahan, Jurusan Teknik Sipil Politeknik Negeri Manado. Metode yang digunakan dalam penelitian ini adalah experimental dengan simulasi pembebanan sebagai uji kuat tekan dan kuat lentur. Model paving block yang diteliti berupa paving block dengan bentuk persegi panjang berdimensi benda uji lebar $=10 \mathrm{~cm}$, tebal $=8 \mathrm{~cm}$ dan panjang $=20 \mathrm{~cm}$. Hasil menunjukan bahwa paving normal mempunyai nilai mutu yang lebih kecil dari paving block dari limbah plastik yang diteliti, juga dari segi biaya paving block dari limbah plastik lebih murah dari pada paving block normal.
\end{abstract}

Kata Kunci- Paving block, konstruksi, limbah plastik

\begin{abstract}
Plastic waste that is normally dirty, smell and cause diseases also pollute the environment, actually can be used for lightweight construction products that benefits the human life because of the advantage of using plastic waste is not only for technical parts but also the high economic value of the plastic waste. This research aims to reduce the plastic waste pollutant and to gain the appropriate mixture in making paving block containing plastic waste also to determine the compressive and flexural strength on the plastic paving block by comparing the cost per $\mathrm{m}^{2}$ between plastic paving block and normal paving block. This research was conducted at Laboratorium Uji Material, Politeknik Negeri Manado. The experimental method was used by simulating the external load for compressive and flexural strength test. The paving block was prepared with dimension of $10 \mathrm{~cm}$ width, $8 \mathrm{~cm}$ thick and $20 \mathrm{~cm}$ length. The results show that the quality of normal paving was lower than the plastic paving block, also from the cost side the plastic paving block was found cheaper than the normal paving block.
\end{abstract}

Keywords- Paving block, construction, plastic waste 


\section{PENDAHULUAN}

Paving block dikenal juga dengan sebutan bata beton (concrete block) atau cone block merupakan produk bahan bangunan terbuat dari campuran semen Portland, agregat dan air dengan bahan tambah lainnya yang tidak mengurangi mutu paving block tersebut Paving block biasanya digunakan sebagai salah satu alternatif penutup atau perkerasaan permukaan jalan, selain itu paving block sangat luas penggunaanya untuk berbagai keperluan, mulai dari keperluan yang sederhana sampai penggunaan yang memerlukan spesifikasi khusus. Paving block dapat digunakan untuk pengerasan dan memperindah trotoar jalan di kota-kota, pengerasan jalan dikomplek perumahan atau kawasan pemukiman, memperindah taman, pekarangan dan halaman rumah, pengerasan area parkir, area perkantoran, pabrik, taman dan halaman sekolah (Artiany, 2018).

Dewasa ini paving block banyak yang dibuat dengan menggunakan material limbah maupun sumber daya alam seperti sekam padi (Bakhtiar, 2009; Sherliana dkk, 2016), abu terbang (Sudibyo dkk, 2008; Anggodo, 2014), pasir silika (Luthfizar dkk, 2019), silica fume (Tarru, 2017;Adilah, 2020), ampas tebu (Harijanto dkk, 2014).

Dengan berkembangnya teknologi sangat berpengaruh bagi jalannya kehidupan manusia sekarang ini dan menimbulkan berbagai dampak pada lingkungan, diantaranya tingginya penggunaan plastik untuk konsumsi kehidupan masyarakat. Dengan begitu jumlah sampah plastik otomatis menjadi lebih tinggi dikarenakan konsumsi yang tinggi. Oleh karena latar belakang di atas, ini bermaksud untuk membuat penelitian dengan mengganti bahan baku paving block yang pada umumnya, diganti menjadi campuran batu pecah dan limbah plastik (Murdiyoto, 2011). Bahan baku limbah plastik campuran kerikil ini sebagai bahan substitusi pada campuran paving block ini diharapkan dapat mempunyai ikatan yang baik agar paving block tahan lama dan mengurangi penyerapan air sehingga keawetan paving block dapat meningkat serta memiliki kuat tekan yang lebih tinggi. Selain itu juga, berdasarkan hasil penelitian akan dilihat sejauh mana pengaruh komposisi limbah plastik campuran kerikil terhadap karakteristik paving block serta diharapkan dapat menjadi salah satu upaya untuk mengurangi penggunaan bahan alam dan mereduksi limbah yang berasal dari plastik.

\section{DASAR TEORI}

\subsection{Paving block}

Paving block menurut SNI 03-0691-1996 didefinisikan sebagai suatu komposisi bahan bangunan yang dibuat dari campuran semen portland atau bahan perekat hidrolis sejenisnya, air dan agregat dengan atau tanpa bahan tambahan lainnya yang tidak mengurangi mutu paving block itu. Klasifikasi paving block adalah paving block mutu A yang digunakan untuk jalan, paving block mutu B yang digunakan untuk pelataran parker, paving block mutu C yang digunakan untuk pejalan kaki, paving block mutu D yang digunakan untuk taman dan penggunaan lain.

\subsection{Plastik}

Sampah plastik merupakan sampah yang tidak asing lagi untuk kita jumpai apalagi yang tinggal di perkotaan terlebih khusus di Kota Manado. Kata plastik berasal dari bahasa yunani plastikos yang berarti dapat dibentuk menjadi ukuran yang berbeda-beda. Sejarah plastik 
berlangsung sangat singkat jika dibandingkan dengan sejarah kayu dan logam. Plastik tidak akan ditemukan dibawah tanah maupun melalui panggilan tanah. Plastik terbuat dari bahan kimiawi seperti karbon, silicon, hidrogen, nitrogen, oksigen, dan klorida. Kombinasi yang sangat berbeda dari bahan kimia ini akan menghasilkan berbagai jenis plastik yang berbeda pula. Yakni plastik yang bersifat thermoplastic dan yang bersifat thermoset. Thermoplastic dapat dibentuk kembali dengan mudah dan diproses menjadi bentuk lain, sedangkan jenis thermoset bila telah mengeras tidak dapat melunakan kembali. Plastik yang paling umum digunakan dalam kehidupan sehari-hari adalah dalam bentuk thermoplastic.

\subsection{Agregat}

Agregat atau abu batu adalah sekumpulan butir- butir batu pecah, kerikil, pasir, atau mineral lainnya baik berupa hasil alam maupun buatan (SNI No: 1737-1989-F). Agregat atau abu batu adalah material granular, misalnya pasir, kerikil, batu pecah yang dipakai bersamasama dengan media pengikat, yaitu semen untuk membuat suatu bahan bangunan seperti paving block. Agregat atau abu batu merupakan butir-butir batu pecah split, kerikil, pasir atau mineral lain, baik yang berasal dari alam maupun bu.atan yang berbentuk mineral padat berupa ukuran besar mauppun kecil atau fragmen-fragmen.

\subsection{Cara Mengolah dan Pelelehan Limbah Plastik}

Dalam mengolah sampah plastik yang efektif, perlu sekali upaya yang menyeluruh. Baik ditingkat pencegahan atau antisipasi sebelum dibuang, sampai bagaimana pengolahannya ketika sudah ditingkat daur ulang. Hal yang terbaik sebenarnya adalah langkah bagaimana sampah plastik itu sebelum dibuang atau daur ulang.

Dalam membuat paving block dari sampah plastik itu dengan cara membakar sampah plastik. Sebelumnya plastik dipotong kecil-kecil (dicacah), untuk mempermudah disaat pembakaran. Sehingga menjadi bubur plastik (lumer), dengan suhu yang ditentukan, $130-180^{\circ} \mathrm{C}$ setelah itu bubur plastik yang masih panas dicampur dengan kerikil (batu pecah), lalu diaduk hingga rata, kemudian adonan campuran bubur plastik itu dimasukkan ke dalam cetakan dan dipress.

\subsection{Jenis dan Ukuran Paving block}

Adapula tipe ukuran serta jenis-jenis model paving block yaitu paving block /conblock tipe batu dengan ukuran (dimensi 10,5 cm x $21 \mathrm{~cm}$ dan ketebalan $6 \mathrm{~cm}, 8 \mathrm{~cm}, 10 \mathrm{~cm}$ ), paving block / conblock tipe cacing dengan ukuran (dimensi 11,5 cm x 22,5 cm dan ketebalan $6 \mathrm{~cm}, 8$ $\mathrm{cm}, 10 \mathrm{~cm}$ ), paving block / conblock tipe segitiga dengan ukuran (dimensi 19,7 cm x 9,6 cm dan ketebalan $6 \mathrm{~cm}, 8 \mathrm{~cm}, 10 \mathrm{~cm}$ ), paving block / conblock tipe segi enam dengan ukuran (dimensi $20 \mathrm{~cm}$ x $20 \mathrm{~cm}$ dan ketebalan $6 \mathrm{~cm}, 8 \mathrm{~cm}, 10 \mathrm{~cm}$ ), paving block / conblock tipe topi uskup dengan ukuran (dimensi $30 \mathrm{~cm}$ x $6 \mathrm{~cm}$ x $21 \mathrm{~cm}$ dan ketebalan $6 \mathrm{~cm}, 8 \mathrm{~cm}, 10 \mathrm{~cm}$ ).

\subsection{Mesin Press Hidrolik}

Mesin press hidrolik adalah mesin yang memiliki dudukan atau plat dimana bahan logam ditempatkan sehingga dapat dipress, dihancurkan, diluruskan atau dibentuk. Dan menyatakan bahwa ketika tekanan diterapkan pada cairan dalam sistem tertutup, tekanan diseluruh sistem selalu tetap / konstan. Dengan kata lain, mesin press hidrolik adalah mesin yang memanfaatkan tekanan yang diberikan pada cairan untuk menekan, mengepress, membentuk sesuatu. 


\subsection{Kuat Tekan Paving block}

Menurut SNI 03-0691-1996, kuat tekan paving block adalah besarnya beban per satuan luas, yang menyebabkan benda uji beton hancur bila dibebani dengan gaya tekan tertentu yang dihasilkan oleh mesin tekan. Kuat tekan maksimum diberikan persamaan berikut:

$$
\mathrm{f}^{\prime} \mathrm{c}=\frac{P}{L}
$$

Dimana :

$\mathrm{f}^{\prime} \mathrm{c}=$ Kuat Tekan $(\mathrm{MPa})$

$\mathrm{P}=$ Beban maksimum $(\mathrm{N})$

$\mathrm{L}=$ Luas bidang permukaan (mm2)

\subsection{Kuat Lentur Paving block}

Pengujian kuat lentur dilakukan berdasarkan standar ASTM C78 - 21 dengan metode Third-Point Loading. Tujuan dari pengujian ini adalah untuk mengetahui modulus of rupture, yaitu kuat lentur maksimum yang dialami oleh benda uji. Pengujian kuat lentur dilakukan pada umur 7 hari dan 28 hari. Hasil dari metode uji ini dapat digunakan untuk menentukan kesesuaian terhadap spesifikasi atau sebagai dasar untuk menentukan proporsi, mencampur dan melaksanakan pengecoran. Untuk mendapatkan hasil kuat lentur maksimum menggunakan persamaan sebagai berikut :

$\mathrm{R}=\frac{3 P l}{2 b d^{2}}$

Dimana :

$\mathrm{R}=$ Modulus runtuh $(\mathrm{MPa})$

$\mathrm{P}=$ Beban maksimum $(\mathrm{N})$

1 = Panjang bentang $(\mathrm{mm})$

$\mathrm{b}=$ Rata-rata lebar benda uji $(\mathrm{mm})$

$\mathrm{d}=$ Rata - rata ketinggian benda uji $(\mathrm{mm})$

\section{METODE PENELITIAN}

Metode penelitian yang digunakan dalam penelitian ini adalah studi eksperimental. Pelaksanaan testing atau uji coba dilaksanakan di Laboratorium dengan diagram alir sperti pada Gambar 1. Dengan tahapan penelitian sebagai berikut:

1. Melakukan pengumpulan data melalui pengujian material semen dan agregat halus, perencanaan campuran paving block plastik, pembuatan benda uji, dan pengujian benda uji

2. Mempersiapkan dan menyediakan bahan, pemeriksaan sifat fisik material, berupa pemeriksaan kadar air, Pemeriksaan Berat Jenis dan Penyerapan Agregat Halus, Pemeriksaan Berat Isi/Volume Agregat, Pemeriksaan Gradasi/Ayakan Agregat, Pemeriksaan Kadar Lumpur.

3. Setelah komposisi campuran yang tepat diperoleh, selanjutnya di buat benda uji yang akan digunakan.

4. Melakukan pengujian paving berupa Kuat Tekan dan Kuat Lentur 


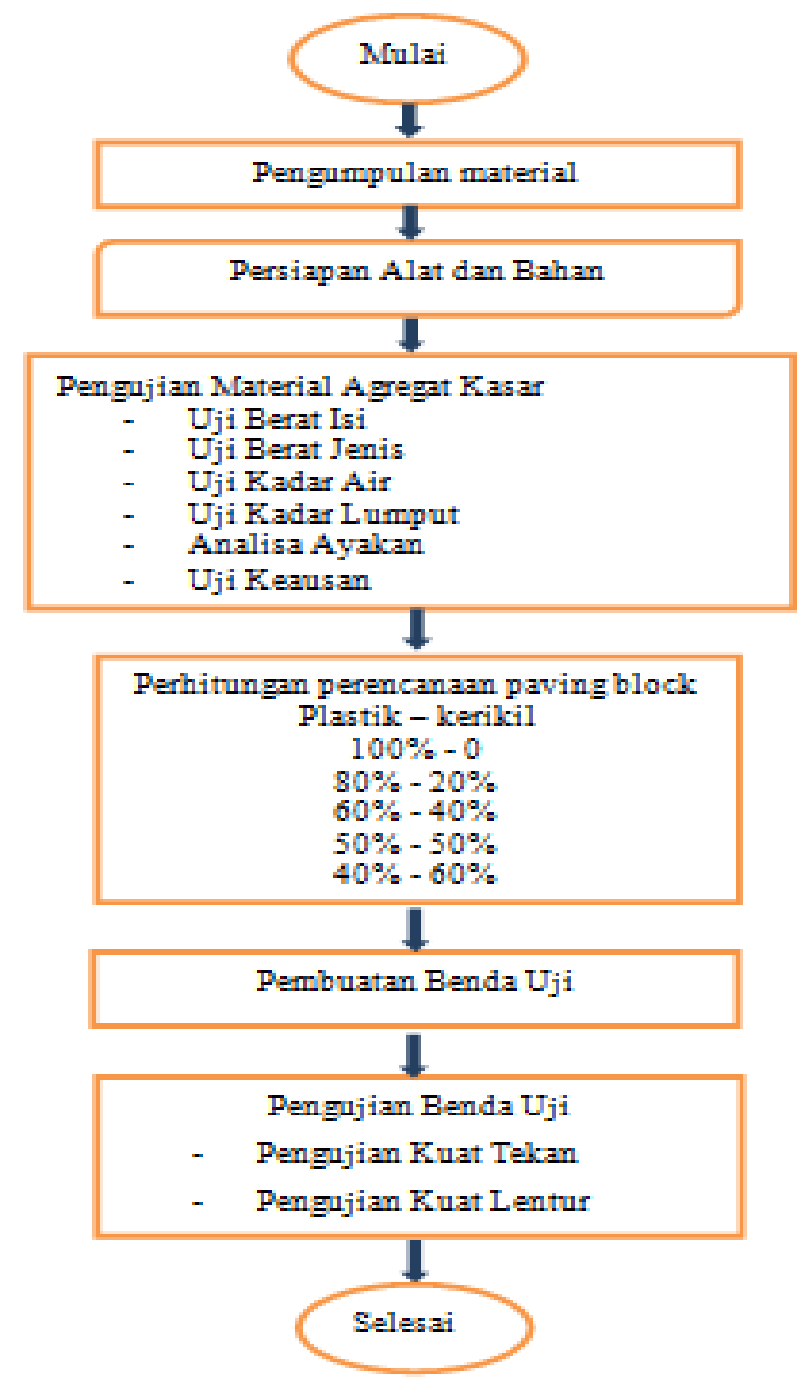

Gambar 1. Diagram Alir Penelitian

\subsection{Perencanaan campuran paving block}

Percobaan campuran paving block menggunakan perbandingan antara limbah plastik dan kerikil. Percobaan ini menggunakan beberapa perbandingan campuran (plastik: kerikil), yaitu plastik 100\%, 50\% : 50\%, 80\% : 20\%, 60\% : 40\% dan, 40\%:60\%. Berdasarkan perencanaan campuran paving block. Maka diperoleh bahan untuk 1 buah paving block. Adapun tabel perencanaan pembuatan paving block, serta perhitungan proporsi perencanaan dapat dilihat pada Tabel 1 .

Tabel 1. Perencanaan Pembuatan Paving block

\begin{tabular}{lccccc}
\hline Plastik & $100 \%$ & $50 \%$ & $80 \%$ & $60 \%$ & $40 \%$ \\
\hline Kerikil & - & $50 \%$ & $20 \%$ & $40 \%$ & $60 \%$ \\
\hline
\end{tabular}

Seluruh pembuatan benda uji mengacu pada Standar Internasional yang menggunakan cetakan paving block berdimensi $20 \mathrm{~cm}$ x $10 \mathrm{~cm}$ x $8 \mathrm{~cm}$ untuk satu buah benda uji. Untuk jumlah 
pembuatan benda uji adalah sebanyak 30 buah dan itu dibagi 2 yaitu 15 untuk kuat tekan dan 15 untuk kuat lentur.

\subsection{Metode pembuatan paving block plastik}

Pengumpulan bahan sampah plastik untuk penelitian, maka selanjutnya proses penelitian dilakukan dengan cara limbah plastik yang sudah disiapkan melalui proses pencacahan (Gambar 2), dibakar pada wadah yang telah disediakan sampai pada titik kekentalan yang tertentu agar hasil paving yang diinginkan memiliki kualitas yang baik, kemudian dituang kedalam cetakan paving block, selanjutnya dipress sampai padat dengan kekuatan tekan $5-8$ ton (Gambar 3), kemudian diuji kuat tekan dan kuat lentur. Hasil paving block yang dihasilkan terlihat pada Gambar 4. Adapun agregat kasar yang digunakan dalam penelitian ini adalah agregat yang berasal dari quarry Kema.

Dalam menentukan campuran paving block terlebih dahulu dilakukan percobaan campuran dengan menentukan beberapa komposisi campuran paving block yang akan diuji kuat tekan untuk melihat campuran yang memberikan nilai kuat tekan terbaik.

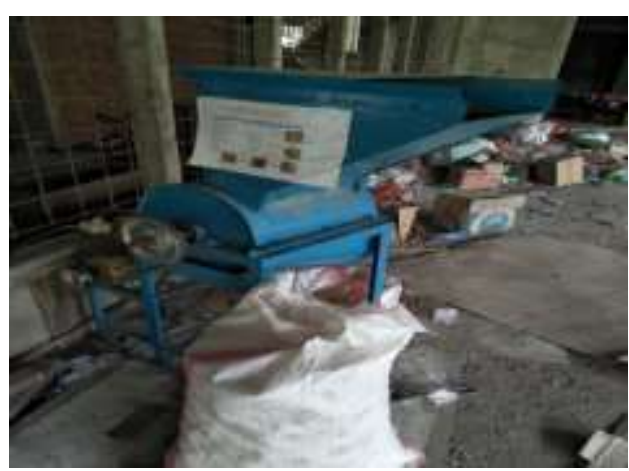

Gambar 2. Alat Pencacah Plastik

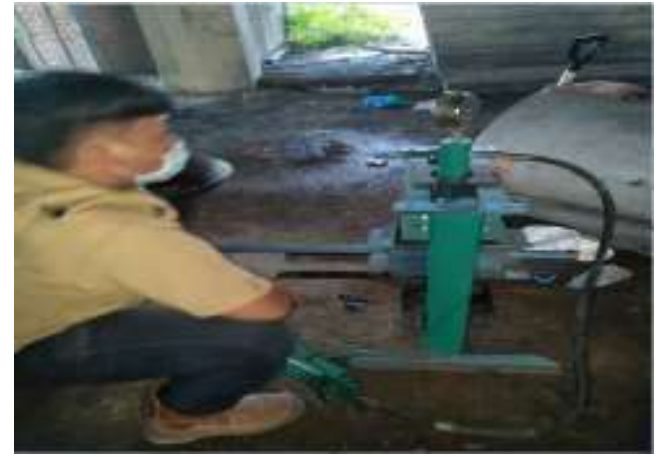

Gambar 3. Alat Pres Paving Block Plastik

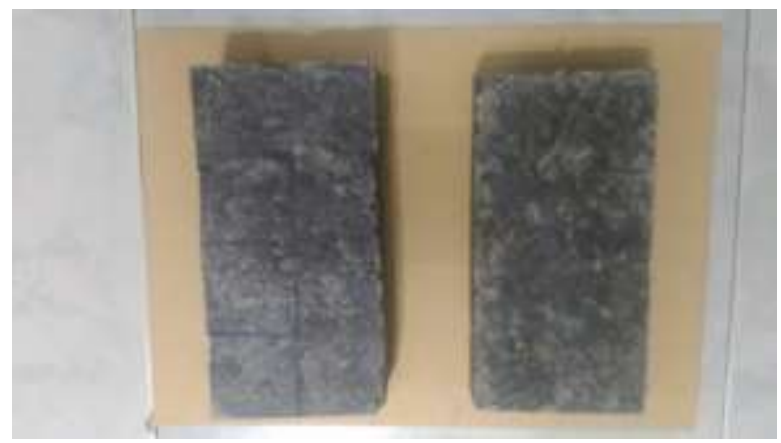

Gambar 4. Hasil Paving Block Plastik

\section{HASIL DAN PEMBAHASAN}

\subsection{Kuat tekan dan kuat lentur paving block}

Berdasarkan data hasil pengujian maka didapatkan data-data pengujian sebagaimana pada Tabel 2. Dimana berdasarkan tabel ini terlihat bahwa campuran paving block dengan menggunakan $50 \%$ plastik dan 50\% kerikil dapat memberikan kekuatan tekan tertinggi yakni 50,97 MPa dimana peningkatannya diakibatkan oleh adanya penambahan kerikil. Walaupun 
demikian, penambahan kerikil sampai $60 \%$ justru menurunkan nilai kuat tekan. Untuk hasil pada kuat lentur diperoleh nilai yang cukup bervariasi dimana kuat lentur tertinggi justru dicapai oleh paving block dengan prosentase $100 \%$ plastik.

Berdasarkan SNI 03-0691-1996 (lihat Tabel 3), paving block dengan variasi 100\%, 50\%:50\%, 80\%:20\%, 60\%:40\%, 40\%:60\%, nilai kuat tekan rata-rata berturut-turut sebesar 31,72 MPa, 50,97 MPa, 24,38 MPa, 49,45 MPa dan, 39,77 MPa dapat dikategorikan ke dalam kategori mutu A, yaitu digunakan untuk jalan. Hal ini berdasarkan spesifikasi kategori mutu A yang memiliki kuat tekan minimal $35 \mathrm{MPa}$. Dan hasil lainnya dapat dikategorikan ke dalam kategori mutu B, yaitu digunakan untuk pejalan kaki. Berdasarkan spesifikasi kategori mutu B yang memiliki kuat tekan minimal $17 \mathrm{MPa}$. Sedangkan untuk kuat lentur paving block belum ada ketentuan kuat lentur untuk tiap mutunya. Belum ada batas minimum kuat lentur paving block.

Tabel 2. Kuat tekan dan kuat lentur campuran paving block

\begin{tabular}{lccc}
\hline \multicolumn{1}{c}{ Campuran } & Kuat tekan (MPa) & Kuat lentur (MPa) & SNI 03-0691-1996 \\
\hline PL 100\% & 31,72 & 7,57 & MUTU B \\
PL80\%+KR20\% & 24,38 & 1,89 & MUTU B \\
PL60\%+KR40\% & 49,45 & 2,82 & MUTU A \\
PL50\%+KR50\% & 50,97 & 1,73 & MUTU A \\
PL40\%+KR60\% & 39,77 & 2,13 & MUTU A \\
\hline
\end{tabular}

Tabel 3. Ketentuan berdasarkan SNI 03-0691-1996

\begin{tabular}{cccccc}
\hline Mutu & \multicolumn{2}{c}{ Kekuatan $(\mathrm{MPa})$} & \multicolumn{2}{c}{ Kekuatan Aus } & $\begin{array}{c}\text { Penyerapan air (rata-rata } \\
\text { maksimal) }\end{array}$ \\
\cline { 2 - 4 } & Rata-rata & Minimal & Rata-rata & Maksimal & 3 \\
\hline A & 40 & 35 & 0,090 & 0,103 & 6 \\
B & 20 & 17 & 0,130 & 0,130 & 8 \\
C & 15 & 12,5 & 0,160 & 0,184 & 10 \\
D & 10 & 8,5 & 0,251 & 0,251 & \\
\hline
\end{tabular}

Gambar 5 di bawah ini menunjukkan korelasi antara kuat tekan dan kuat lentur dari paving block dimana kuat tekan tertinggi dengan perbandingan 50\%:50\% memiliki nilai kuat tertinggi sebesar 50,97 $\mathrm{MPa}$, dengan nilai kuat lentur terendah sebesar 1,73 MPa. Hal ini disebabkan karena sifat plastik yang sudah mengeras sampai pada batas jenuh sehingga paving block tidak dapat menahan beban lentur yang ada. 


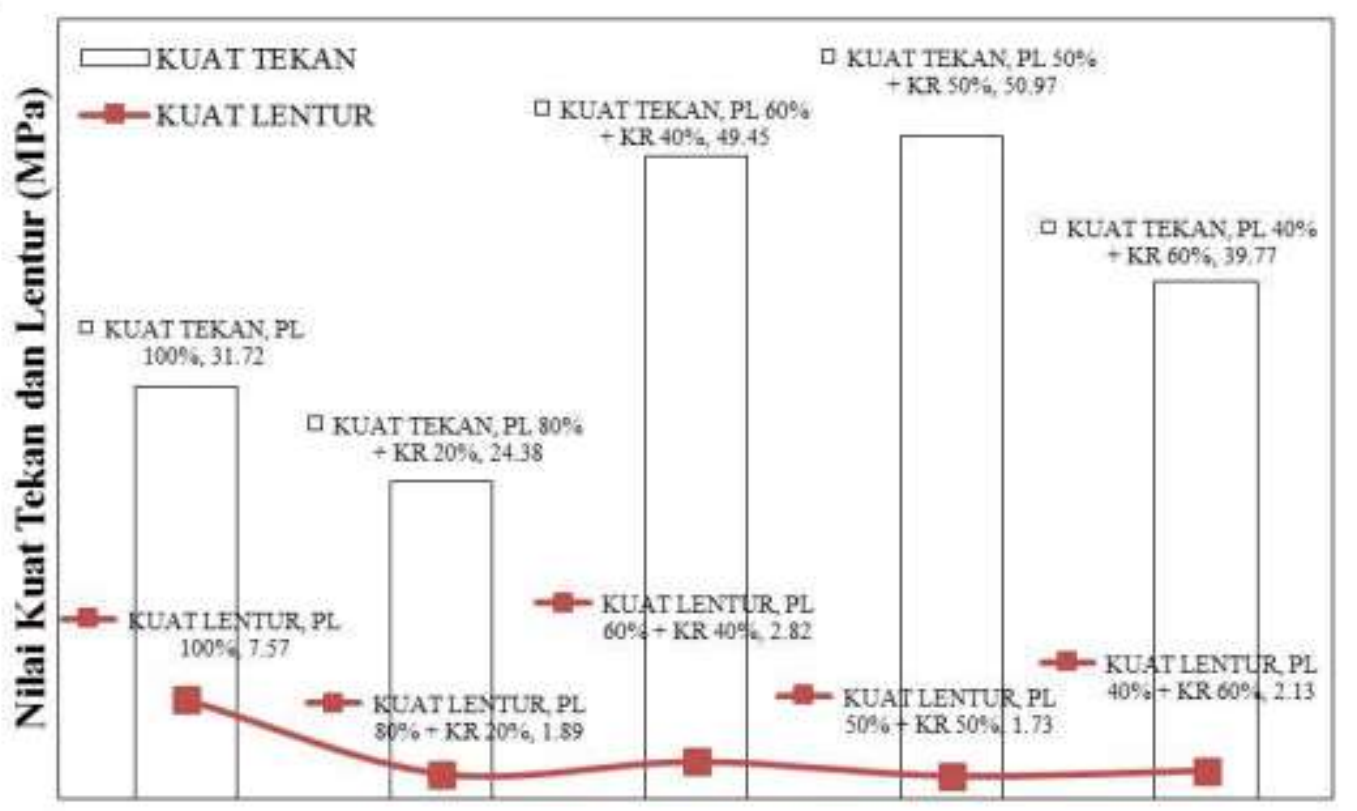

Proporsi Campuran

Gambar 5. Korelasi antara kuat tekan dan kuat lentur

\subsection{Perhitungan biaya paving block plastik}

Berdasarkan hasil penelitian dan perhitungan biaya yang dilakukan maka didapat biaya paving block normal yang ada dipasaran Rp. 3000/buah. Berdasarkan tujuan penelitian yang akan dihitung per $m^{2}$ diperoleh bahwa jumlah paving block per $m^{2} 50$ buah dengan harga Rp. $150.000,00$. Untuk paving block $100 \%$ (plastik) per $m^{2} 50$ buah dengan harga Rp. 264,000.00. Untuk paving block 50\%: 50\% (plastik : kerikil) per $m^{2} 50$ buah dengan harga Rp. 139,031.83. Untuk paving block 80\%: 20\% (plastik : kerikil) per $m^{2} 50$ buah dengan harga Rp. 209,163.90. Untuk paving block 60\%: 40\% (plastik : kerikil) per $m^{2} 50$ buah dengan harga Rp. 162,522.88. Untuk paving block 40\%: 60\% (plastik : kerikil) per $m^{2} 50$ buah dengan harga Rp 115,498.37. Rekapitulasi harga paving block plastik dapat dilihat pada Tabel 4.

Tabel 4. Rekapitulasi harga paving block plastik

\begin{tabular}{ccccc}
\hline \multicolumn{5}{c}{ Rekapitulasi Harga Paving block Plastic Per $\mathrm{m}^{2}$} \\
\hline Viriasi & Jumlah & Satuan & Harga per buah & Harga per $\mathrm{m}^{2}$ \\
\hline $100 \%$ & 50 & $\mathrm{M}^{2}$ & Rp. 5.280,00 & Rp. 264.000,00 \\
\hline $80 \%: 20 \%$ & 50 & $\mathrm{M}^{2}$ & Rp. 4.183,28 & Rp. 209.163,90 \\
\hline $60 \%: 40 \%$ & 50 & $\mathrm{M}^{2}$ & Rp. 3.250,46 & Rp. 162.522.88 \\
\hline $50 \%: 50 \%$ & 50 & $\mathrm{M}^{2}$ & Rp. 2.780,64 & Rp. 139.031,83 \\
\hline $40 \%: 60 \%$ & 50 & $\mathrm{M}^{2}$ & Rp. 2.309,97 & Rp. 115.498,37 \\
\hline
\end{tabular}




\section{KESIMPULAN}

Berdasarkan penelitian yang telah dilakukan, maka dapat disimpulkan bahwa omposisi campuran paving block yang berbanding 50\% plastik, dan 50\% kerikil memiliki nilai kuat tekan tertinggi sebesar 50,97 MPa. Maka komposisi campuran ini bisa menjadi rekomendasi diperjual belikan dengan penggunaan pada struktur jalan. Adapun dari semua campuran variasi paving block limbah plastik ini yang di uji ternyata hanya jenis A dan B yang masuk dalam standar SNI. Pada campuran variasi $100 \%$ (plastik) kelas B, dengan kekuatan 31,71 MPa, dan 50\% (plastik) : 50\% (kerikil) kelas A, $50.97 \mathrm{MPa}, 80 \%$ (plastik) : 20\% (kerikil) kelas B, 24,38 MPa, 60\% (plastik) : 40\% (kerikil) kelas A, 49,45 MPa dan 40\% (plastik) : 60\% (kerikil) kelas A, 39,77 MPa. dengan rerata nilai kuat lentur adalah 7,57 MPa, 1,89 $\mathrm{MPa}, 2,82 \mathrm{MPa}, 1,73 \mathrm{MPa}$, dan 2,13 MPa. Sesuai hasil korelasi kuat tekan dengan nilai tertinggi memiliki kuat lentur terendah. Berdasarkan hasil analisa dan perhitungan biaya paving block biasa dan paving block limbah plastik, yang paling ekonomis pada campuran 50\%: 50\%. Yang mempunyai standar mutu A dan kuat tekan 50.97 MPa, dengan harga Rp. 139,031.83. per $\mathrm{m}^{2}$

\section{SARAN}

Setelah melakukan penelitian, maka saran yang diberikan untuk penelitian selanjutnya adalah supaya lebih memperhatikan jangka waktu atau umur perawatan paving block limbah plastik. Selain itu perlu dilakukan pemeriksaan alat yang akan digunakan termasuk saat menggunakan mesin pres karena hasil pembakaran dari limbah plastik sangat cepat keras, dan dicetak dalam keadaan panas atau cair.

\section{UCAPAN TERIMA KASIH}

Penulis mengucapkan terima kasih atas pendanaan penelitian melalui Penelitian Internal Politeknik Negeri Manado Tahun 2021.

\section{DAFTAR PUSTAKA}

Adilah, F. (2020). Pengaruh campuran silica fume sebagai pengganti sebagian semen dalam pembuatan paving block dengan metode tekanan. SKRIPSI-S1. Fakultas Teknik. Universitas Muhammadiyah Surakarta.

Anggodo, A. (2014). Pengaruh penggunaan abu batu bara (fly ash) terhadap kuat tekan paving block. Jurnal Teknik Sipil dan Arsitektur, Vol. 4, No.1.

Artiani, G.P. (2018). Bahan konstruksi ramah lingkungan dengan pemanfaatan limbah botol plastik kemasan air mineral dan limbah kulit kerang hijau sebagai campuran paving block. Jurnal Konstruksia, Vol. 9, No.2, hal. 25-30.

ASTM C78/C78M-21. Standard Test Method for Flexural Strength of Concrete (Using Simple Beam with Third-Point Loading), ASTM International, West Conshohocken, PA, 2021, www.astm.org.

Bakhtiar, A. (2009). Studi peningkatan mutu paving-block dengan penambahan abu sekam padi. Jurnal Portal, Vol. 1, No.2, Oktober 2009, hal. 73-80.

Harijanto, F.D, Kasiati, E, Wibowo, B, Arifin, S. (2014). Penambahan abu ampas tebu dan limbah boma bisma indra untuk pembuatan paving block. Jurnal Aplikasi, Vol.12, No.1, Februari 2014. 
Kurniatym R.D., (2011). Pemanfaatan hasil pengolahan sampah sebagai alternatif bahan bangunan konstruksi. Jurnal Smartek, Vol.9, No.1, hal. 47-60.

Luthfizar, G.Y, Puji, F.S, dan Akbari, T. (2019). Pemanfaatan limbah pasir silika sebagai bahan pengganti pasir untuk pembuatan paving block. JURNALIS, Vol. 2, No.1, Februari 2019.

Murdiyoto, A.R., (2011). Pemanfaatan limbah botol plastik jenis PET (poly-ethylene terephalate) untuk agregat kasar pembuatan paving block. TESIS MAGISTER, Program Studi Ilmu Material, Universitas Indonesia, Juli 2011.

Sherliana, (2016). Studi kuat tekan paving block dengan campuran tanah, semen dan abu sekam padi menggunakan alat pemadat modifikasi. Jurnal Rekayasa Sipil dan Desain, Vol.4, No.1, hal. 99-112.

SNI 03-0691-1996, Paving blok. Badan Standardisasi Nasional Indonesia.

SNI 1737-1989-F, Tata cara pelaksanaan lapis aspal beton (laston). Direktorat Henderal Bina Marga.

Sudibyo, G.H, Haryanto, Y, Fatkhurrozak, F. (2008). Abu terbang (fly ash) sebagai bahan tambah untuk meningkatkan kuat tekan bata beton (paving block), Dinamika Rekayasa, Vol. 4, Np.2, hal. 65-76.

Susatyo, A.P., Watiningsih, T, dan Rustendi, I. (2014). Sampah sebagai bahan baku pembuatan bata. Prosiding SEMNAS ENTERPRENEURSHIP, Juni 2014, hal, 275-294, ISBN: 978602-8047-99-9.

Tarru, R.O. (2017). Studi penggunaan silica fume sebagai bahan pengisi (filler) pada campuran beton. Journal Dynamic Saint, Vol.3, No.1, hal. 472-485. 